DOI: http://doi.org/10.52716/jprs.v11i3.533

\title{
Enhancing the Rheological Properties of Water-Based Drilling Fluid by Utilizing of Environmentally-Friendly Materials
}

\author{
Amel Habeeb Assi ${ }^{1, *}$, Ahmed Abdallah Haiwi ${ }^{2}$ \\ ${ }^{1}$ College of Engineering - Baghdad University \\ ${ }^{2}$ Basra Oil Company \\ *Corresponding Author E-mail: zahraa_z91@yahoo.com \\ 2ahmed.ah75@yahoo.com
}

Received 31/1/2021, Accepted 16/3/2021, Published 19/9/2021

This work is licensed under a Creative Commons Attribution 4.0 International License.

\begin{abstract}
$\underline{\text { Abstract }}$
Recently, many materials have shown that they can be used as alternatives to chemicals materials in order to be used to improve the properties of drilling fluids. Some of these materials are banana peels and corn cobs which both are considered environmentally- friendly materials. The results of the X-ray diffraction examination have proved that the main components of these materials are cellulose and hemicellulose, which contribute greatly to the increasing of the effectiveness of these two materials. Due to their distinct composition, these two materials have improved the rheological properties (plastic viscosity and yield point) and reduced the filtration of the drilling fluids to a large extent. The addition rates used for each of the two materials (banana peels and corn cob) are 1\%, 2\%, 3\%, 4\%, 5\% and 6\%. As regard to banana peels, the results have shown that there is a direct correlation between the addition ratios, the increase in the rheological properties (plastic viscosity and yield point), and the decrease in filtration The corn cob has shown the same results. Also, $0.01 \%$ increase in the $\mathrm{pH}$ value was observed when adding a corn cob, while adding banana peels showed the opposite, as adding them led to $0.02 \%$ decrease in the $\mathrm{pH}$ value. Among the other properties that have been studied is density, as it has been noticed that there is no significant effect of these two materials on the density of drilling fluid. Moreover, the performance of these two materials has been compared with the PAC polymer. This research suggests that the possibility of moving towards corn cob and dried banana peels as additives for biodegradable drilling fluid. Apart from being environmentally friendly, the choice of using them is considered economically more efficient than other chemical additives. By all accounts, the above materials are an increasingly rational choice for moving forward for an environmentally friendly oil industry.
\end{abstract}


Keywords: Environmental safety, Rheological property, drilling fluid, additives, filtration.

\section{Introduction:}

Drilling the wellbore is the primary and the furthermost expensive stage in the oil industry. Payments for drilling may be approximately $25 \%$ of the entire oil field exploitation cost and mostly on exploration and the progress of well [1]. Drilling fluids, may have a price of about one fifth (15-18\%) of the entire cost of oil well drilling. However, three significant elements should be focused on: easy to be used, not excessively expensive and environmentally responsive [2].

Given the high environmental stresses on the oil and gas business to stop the damage of marine incomes and coastal environments, the requirement for environmentally responsive clay essences has converted to a right way for environmentally friendly drilling [3 and 4]. That made the production of chemicals additives very important by means of locally waste materials. The anxiety for the environmental care and environmental rules is a growing demand on the oil and industry [5].

The petroleum industry is hopefully investigating drilling muds and its additives for instance non-toxic viscosity governor and fluid loss controller additives in drilling fluid [6]. The practical performance of the drilling mud may not be considered, however, the environmental impact of this mud and its additives shows an important part as it controls the nature of the drilling fluid [7]. It is necessary to confirm the technical and environmental custom of the drilling fluid additive before it can be used [8].

The possibility of using dried banana peels to improve the performance of drilling mud, and the results have enhanced the possibility of using this environmentally friendly material. These researchers used several percentages of dried banana peels, all of which were successful in increasing the viscosity and reducing filtration [9]. Mosier et al found that adding corn cob to drilling mud improves its rheological properties and reduces filtration. This research aims to delve into the impact of local materials that have the potential to decompose and can be considered environmentally friendly and that are not exploited by industrially, such as corn cob 
and dried banana peels in order to improve the efficiency of drilling fluid [10]. With the increase in the global demand for fossil oil, there is an increasing need for economic technologies, such as conducting research on environmentally friendly and at the same time effective materials [11]. The new thing in this research is that a comparison was made between the performance of corn cob and dried banana peels at different concentrations, and then a comparison of the performance of both materials with PAC Polymer, which led to a comprehensive awareness of the effect of both materials on the drilling mud.

\section{Materials:}

\subsection{Corn Cob Cellulose:}

Corncobs are a lignocellulosic substantial collected of cellulose, hemicellulose and lignin. Those polymeric fibers involve monomeric particles. Cellulose is constructed of C6 sugars, hemicellulose mostly of the C5 sugars xylose and arabinose. Lignin is made up of phenolic macromolecules [12]. Hemicellulose and lignin are entrenched in a multifaceted matrix that make them unaffected by to enzymatic poverty (Mosier et al., 2005*; Menon \& Rao, 2012) Hemicellulose, also known as polysaccharide, is a matrix of polysaccharides, such as arabinoxylan, found alongside cellulose in nearly all plant cell walls. It is a polysaccharide present in the biomass of most plants, about 20\% -30\% dry weights of plants. Hemicellulose, along with cellulose, provides the physical and structural strength of the cell wall. In addition to glucose, the other structural components in hemicellulose are xylose, galactose, mannose, rhamnose, and arabinose. Hemicellulose contains shorter chains of 500 and 3000 branched sugar unit. It is obtained by grinding the corn cob until it becomes powdered (pulverized) through a 50 mesh sieve [13 and 14], as shown in Figure (1). It should be noted that the origin of the atom used in this research is southern Mexico, and it was purchased from the supermarket in Baghdad. 


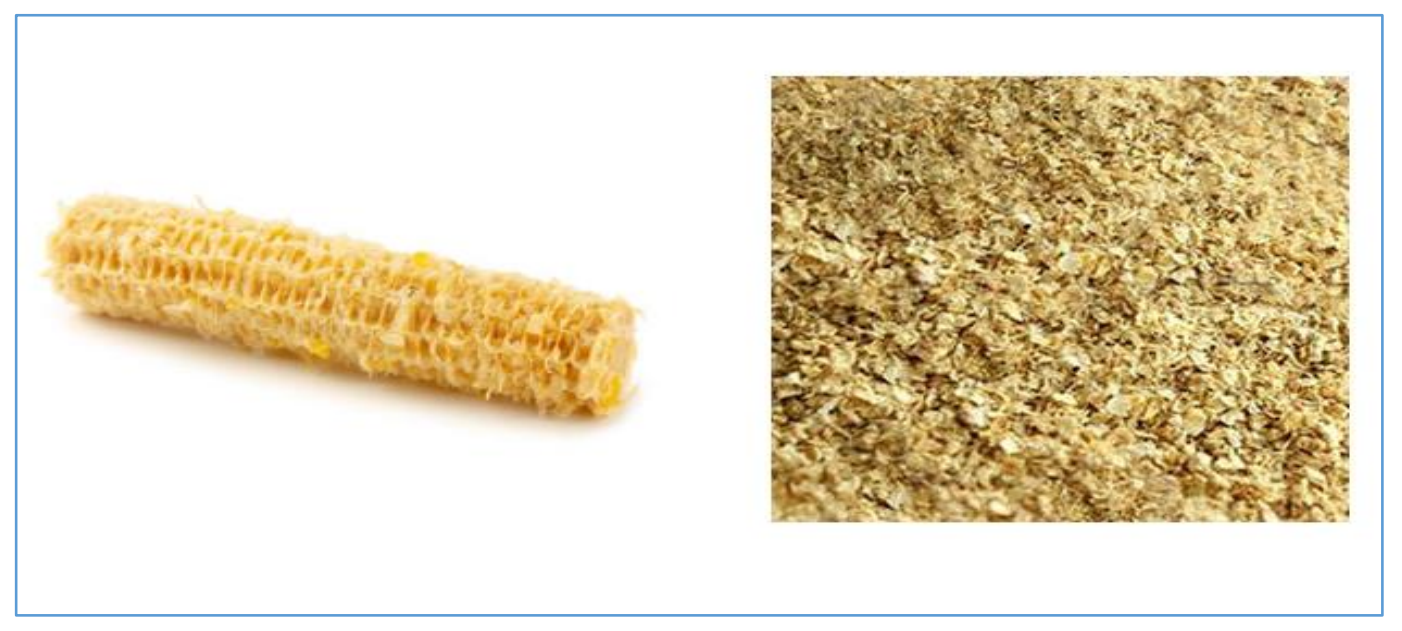

Fig. (1) Corn cob and corn powder.

\subsection{Banana Peel:}

Banana peels were washed with water, dried in the sun for 48 hours, and then dried in a hot oven at $50^{\circ} \mathrm{C}$ for 30 minutes. Then, it is grinded with a regular grinder to pass through a 50 mesh sieve [15 and 16] and as shown in Figure (2). Cellulose $[(\mathrm{C} 6 \mathrm{H} 10 \mathrm{O} 5) \mathrm{n}]$ is the most abundant organic compound on Earth. It is a complex carbohydrate or polysaccharide consisting of hundreds to thousands of glucose molecules, linked together to form a chain. While animals do not produce cellulose, it is made from plants, algae, some bacteria and other microorganisms. Cellulose is the main structural molecule in the cell walls of plants and algae. Cellulose and hemicellulose are two types of natural polymers that are mainly found in plant cell walls and are important components of natural lignocellulose substances. The main difference between cellulose and hemicellulose is that cellulose is an organic polysaccharide molecule while hemicellulose is a matrix of polysaccharides. Cellulose has a strong crystalline structure and is resistant to hydrolysis. Unlike hemicellulose, this has a high molecular weight. Cellulose acts as a support material in plant cell walls. 


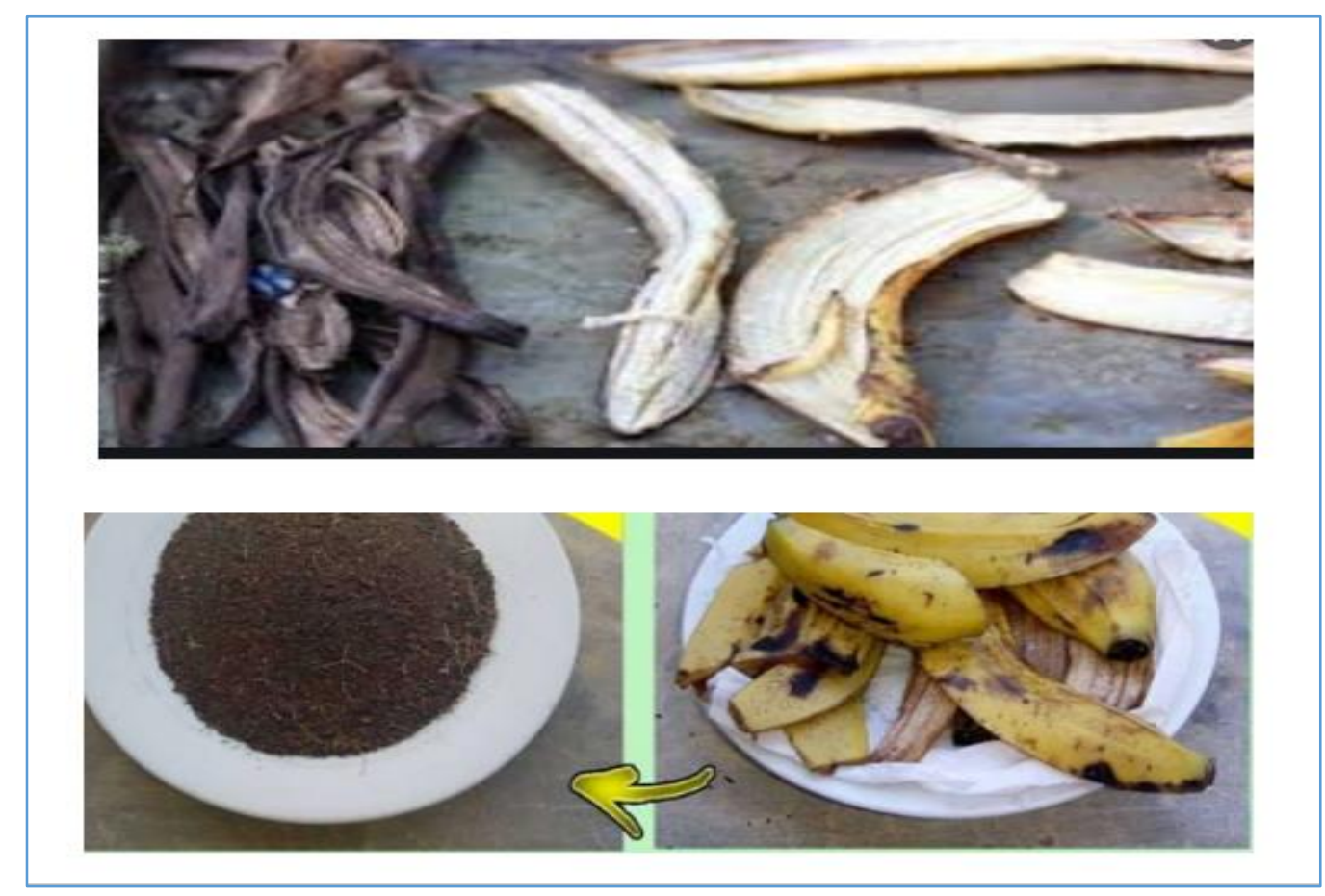

Fig. (2) Dried Banana Peel and Dried Banana Peel Powder

\subsection{Iraqi Bentonite:}

In this effort, the Iraqi bentonite powder, samples of Iraqi bentonite were obtained from the Drilling Laboratory of the Petroleum Engineering Department, University of Baghdad. Chemical configuration for blank bentonite was founded by (XRF) Spectrometry via SHIMADZU XRF-1800, the investigates for Iraqi bentonite, corncobs, banana peel and PAC are shown in Table (1). 
Table (1) XRF analysis for Iraqi bentonite, corncobs, banana peel and PAC

\begin{tabular}{l|llll} 
Component \% & Bentonite & Corncob & Banana peel & PAC \\
\hline $\mathrm{SiO}_{2}$ & 49 & 7.98 & 9.66 & 40 \\
$\mathrm{TiO}_{2}$ & 0.66 & non & non & non \\
$\mathrm{Al}_{2} \boldsymbol{O}_{3}$ & 19 & 9.55 & 2.09 & 10 \\
$\mathrm{Fe}_{2} \mathrm{O}_{3}$ & 6.55 & 8.22 & 1.05 & 1.3 \\
$\mathrm{MnO}$ & 0.7 & 7.55 & 1.38 & non \\
$\mathrm{CaO}$ & 2.44 & 16.55 & 2.29 & 3.04 \\
$\mathrm{MgO}$ & 4.33 & 2.66 & 2.99 & non \\
$\mathrm{Na}_{2} \boldsymbol{O}_{3}$ & 1.99 & 1.66 & 1.99 & 14 \\
$\mathrm{~K}_{2} \mathrm{O}$ & 0.87 & 5 & 4.02 & 2 \\
$\boldsymbol{P}_{2} \boldsymbol{O}_{5}$ & 0.88 & non & 0.66 & 0.34 \\
$\mathrm{Cl}$ & 0.11 & non & non & non \\
$\mathrm{SO}_{3}$ & 0.88 & non & 4.86 & non \\
$\mathbf{L . O} . \boldsymbol{I}$ & 12.59 & 0.83 & non & 0.32 \\
cellulose & non & non & 69.01 & 29 \\
$\mathrm{Hemicellulose}$ & non & 40 & non & non
\end{tabular}

\subsection{PAC:}

It is an enormously extraordinary viscosity fluid loss agent with a too high yield and outstanding viscosifier and has shale inhibiting characteristics [17]. This natural material of unusual purity (> 98\%) acts as a catalyst for the preparation of drilling fluids in order to modify the flow and filtration properties of water-based drilling fluids [18]. Figure (3) shows Iraqi bentonite and PAC polymer.

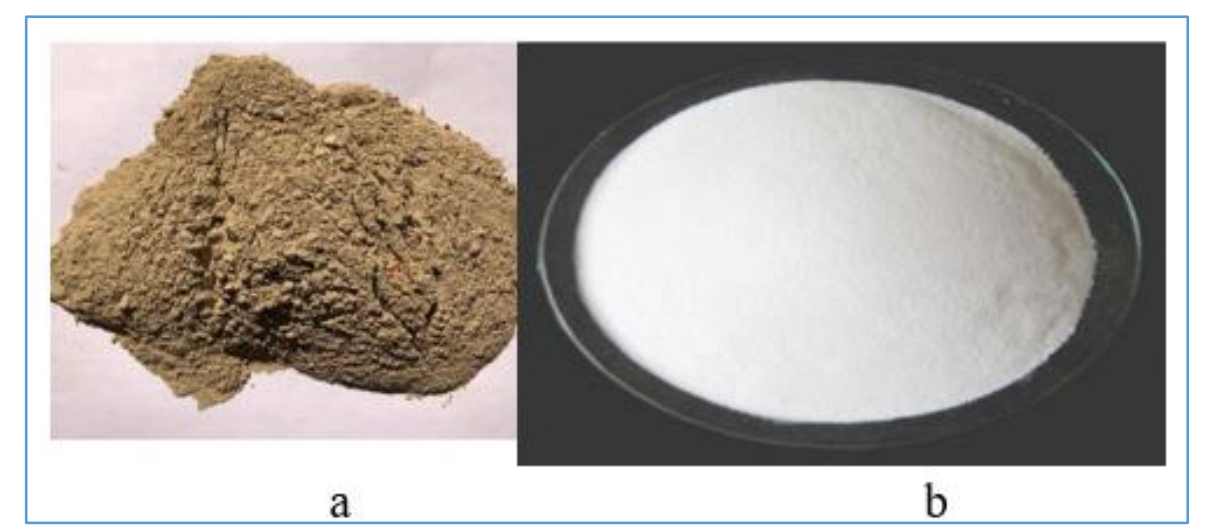

Fig. (3) A represents Iraqi bentonite and b represents PAC 


\section{Apparatus and devices:}

To pass all laboratory tests in this work, the following laboratory equipment and tools are required, as shown in Figure (4):

1. Mud Balance: to measure mud density.

2. Fann Viscometer Model-35: to measure mud rheological properties.

3. API Filter Tester: to measure mud filtration.

4. Oven: helps dry up banana peels

5. $\mathrm{pH}$ indicator strips: to measure $\mathrm{pH}$ of mud. Note that all measurements are at laboratory temperature.

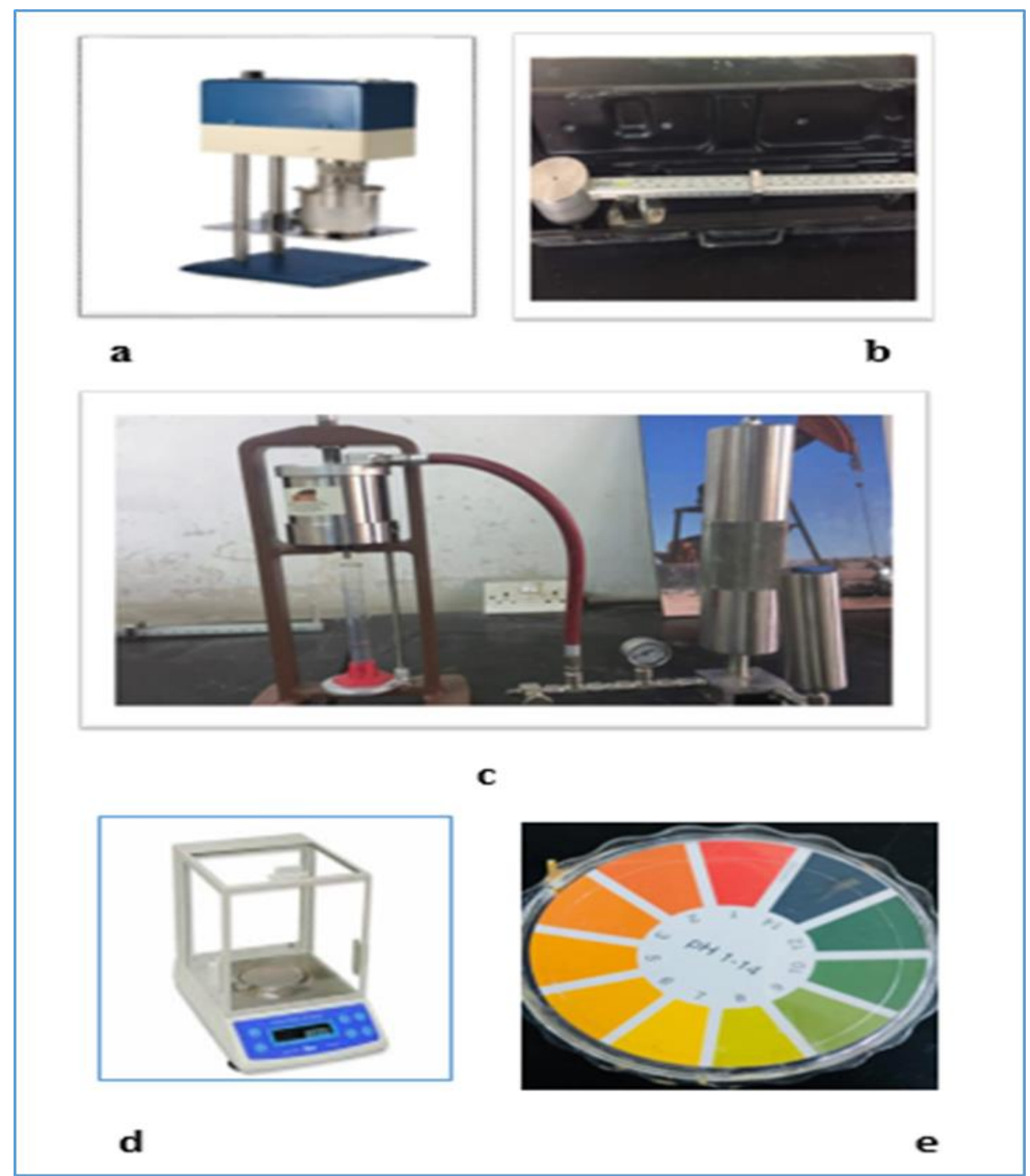

Fig. (4) The device used (a) Fann Viscometer, (b) Mud Balance, (c) API Filter, (d)Electronic balance, (e) pH indicator strip 


\section{Results and Discussion:}

Attention on environmental safety and environmental regulations is focused on the increasing request for the oil and gas exploration manufacturing. The petroleum industry is fortified to seek drilling fluids and their additives for instance non-toxic viscosity reducers and fluid loss control additives in drilling mud [19].The results of X-ray diffraction, as shown in Figure (5) and Table (2), show that the Iraqi bentonite contains a high percentage of montmorillonite, about $73 \%$ as a major mineral This mineral is characterized by the weak cohesion between its plates, as it is rapidly dispersed with water, but its ability to gel is weak. As a result, its ability to gel is not strong because it contains a high percentage of attapulgite, which liberates water easily from inside it. Therefore, its filtration is high and therefore it must be treated with organic colloids that reduce filtration.

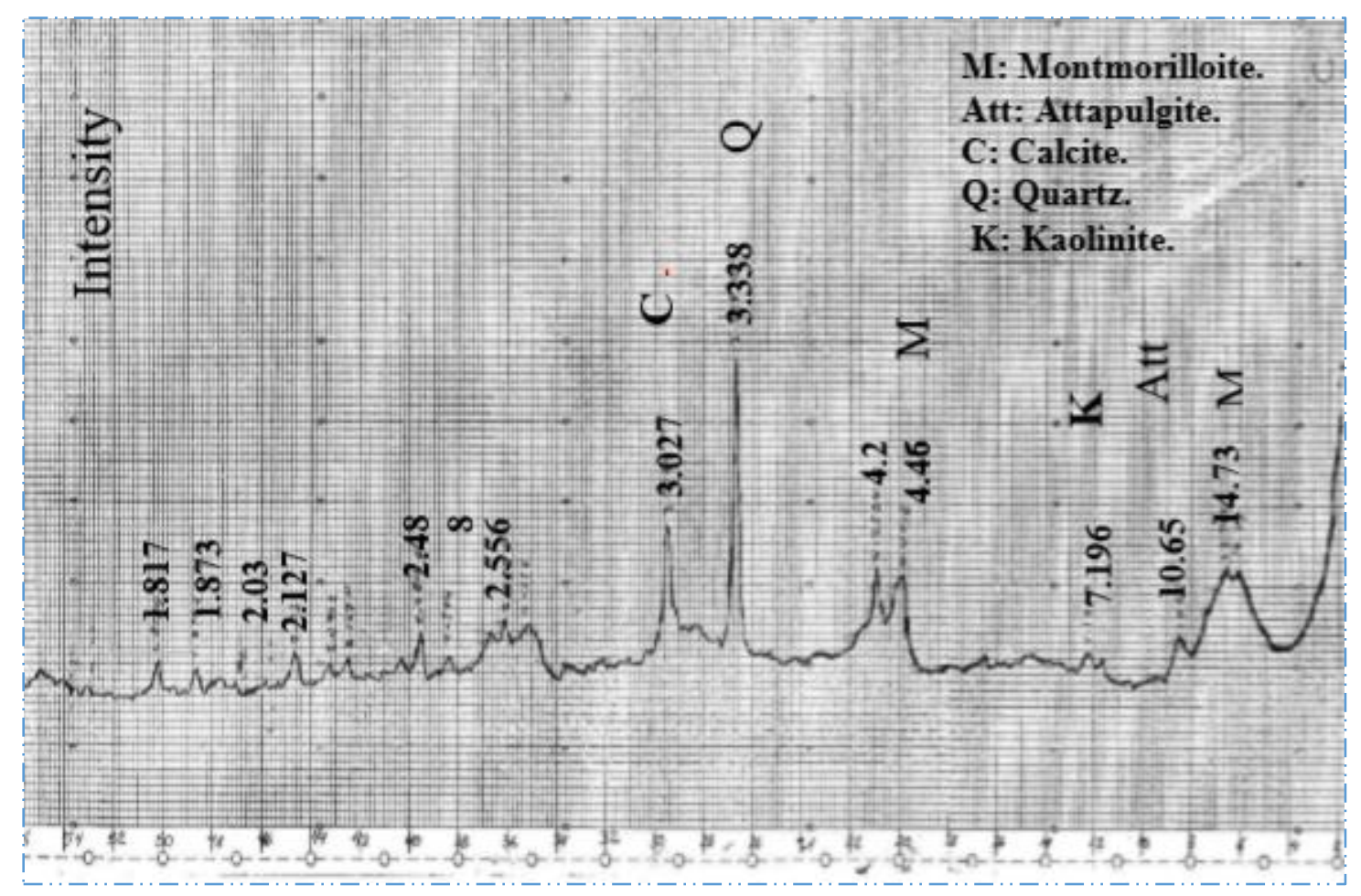

Fig. (5) X-ray diffraction of the Iraqi bentonite powder material 
Table (2) The Iraqi bentonite ore mineral analysis

\begin{tabular}{c|c} 
Mineral Name & Percentage\% \\
\hline Montmorillonite & 72.5 \\
Plygrosktite & 1 \\
Apatite & 16 \\
Calcite & 4 \\
Gypsum & 1 \\
Halite & 1.5 \\
Quartz & 2
\end{tabular}

Figure (6) shows the effect of adding the three additives separately on the viscosity of the Iraqi bentonite. The lowest performance is for the corn cob. As for the dried banana peel, it shows better performance than the corn cob and it is somehow similar to the performance of PAC at the high addition rates of 6 and $5 \%$. Figure (7) shows the effect of adding the three additives on the yield point of the Iraqi bentonite. The least effect was the corn cob. As for the dried banana peel, it showed an average performance between corn cob and PAC, and it was somewhat similar to the performance of PAC at the addition rate of $6 \%$.

Figure (8) shows the effect of adding the three additives on the Iraqi bentonite filtration rate. The most filtered was the corn cob, while the dried banana peel showed an average filtration rate between the corn cob and PAC, and it was equal to the PAC filtration rate at the addition rates of $6 \%$. Figure (9) shows the effect of adding the three additives on the density of Iraqi bentonite. The most effect on the density was the banana peels, while the corn cob had the least effect on the density and PAC had a moderate effect.

Figure (10) shows the thickness of the mud cake and its consistency at an addition rate of $0 \%$ and $6 \%$ of banana peel. The excellent effect of banana peels on the thickness and consistency of the clay cake can be noticed. On the other hand, it can be noticed that the mud is rotting and inconsistent at zero \% additives (Iraqi bentonite alone). This is considered undesirable in drilling operations, of course, because such thickness and lack of cohesion lead to unending problems during 
drilling. Banana peels and PAC have shown the largest effect of giving a coherent and homogeneous mud cake and this is required when drilling wells, while the corn cob showed less uniformity and cohesion and as illustrated in Figure (11). Figure (12) shows the effect of the aforementioned three additives on the thickness of the mud cake, where it was noticed the great and significant improvement in the thickness of the mud cake, especially at an addition rate of $6 \%$, which gave that ratio a coherent and little mud cake required in drilling operations. Table (3) shows the effect of adding the aforementioned three substances on the $10 \mathrm{~min}$ gel strength for the Iraqi bentonite, as the effect of the banana peels and PAC was close, while the corn cob was the least effective. Table (4) shows the effect of adding the aforementioned materials on the acidity value of the drilling fluid as PAC and corn cob contribute to a slight increase in $\mathrm{pH}$ by about $(0.01 \%$ to $0.02 \%)$ and the opposite is quite true for dried banana peels.

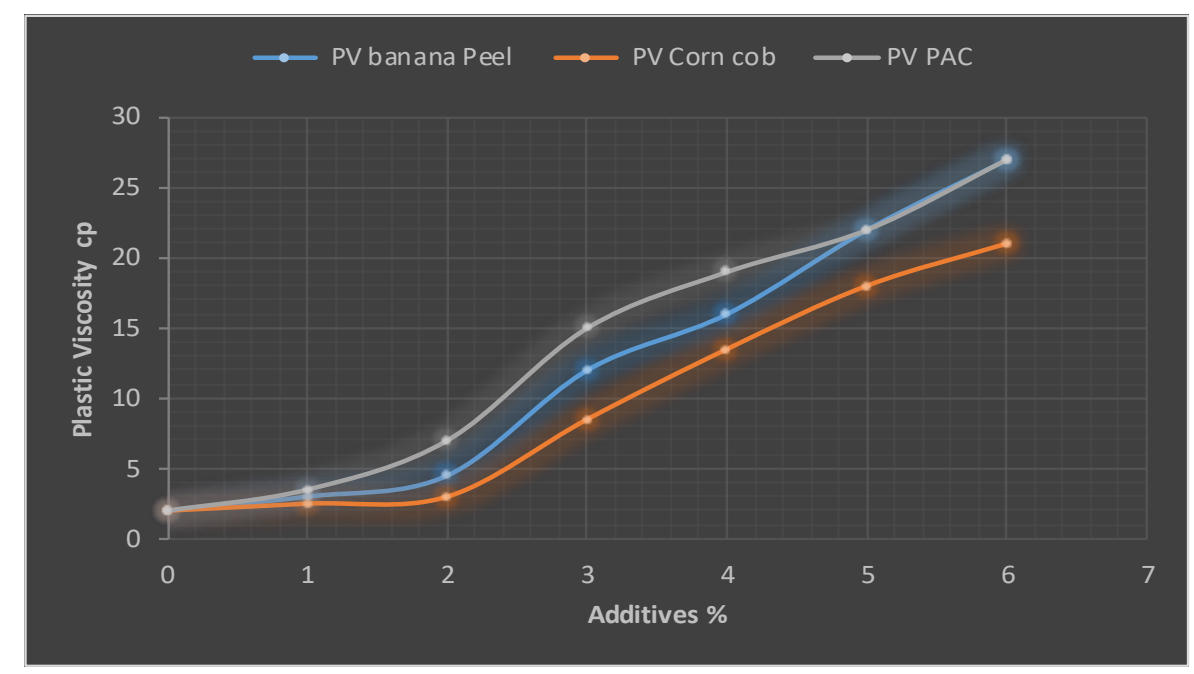

Fig. (6) Effects of adding banana peels, corn cob and PAC on viscosity 
Journal of Petroleum Research and Studies

Open Access

No. 32, September 2021, pp.66-81

$\begin{array}{ll}\text { JPRS } & \text { P- ISSN: 2220-5381 } \\ \text { E- ISSN: 2710-1096 }\end{array}$

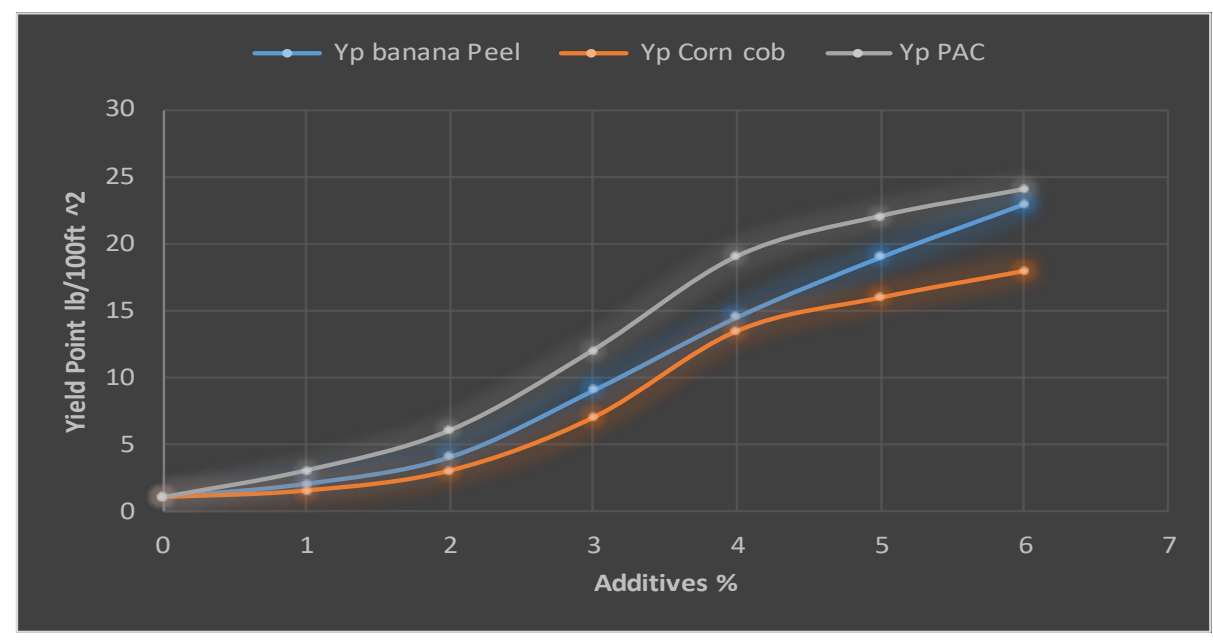

Fig. (7) Effects of adding banana peels, corn cob and PAC on Yp

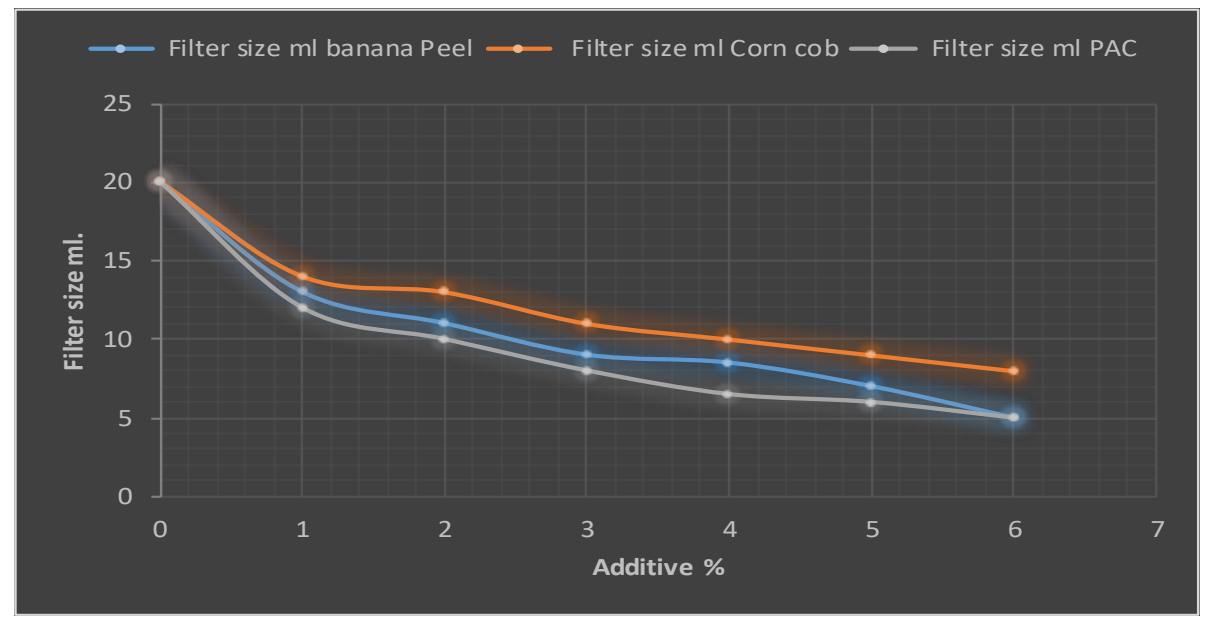

Fig. (8) Effects of adding banana peels, corn cob and PAC on filtration

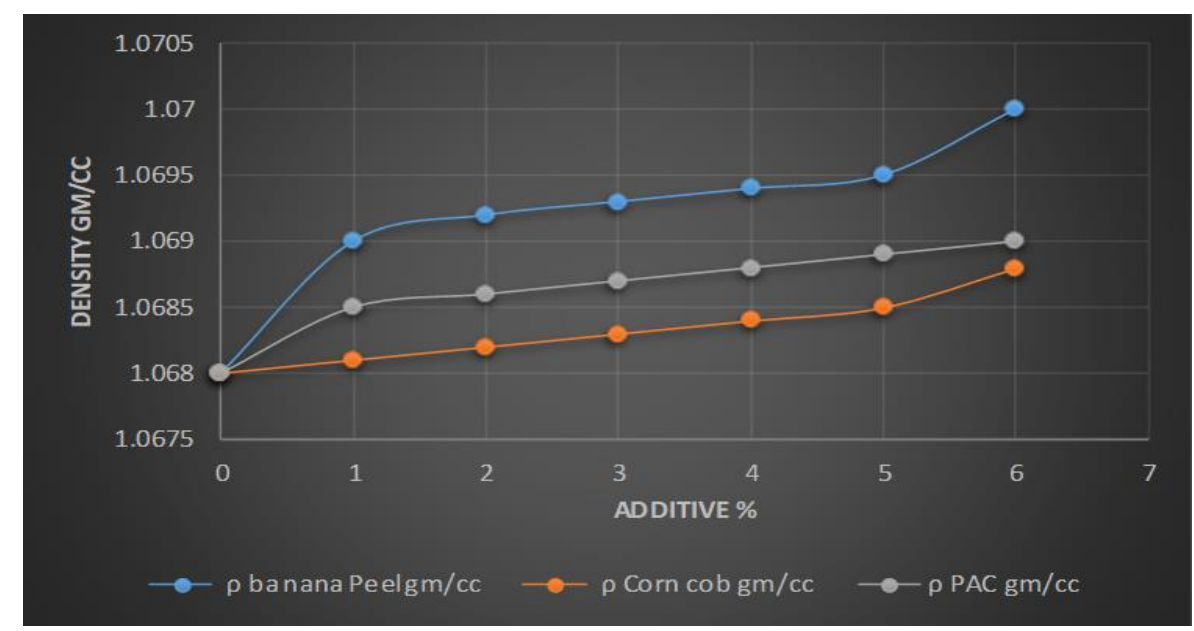

Fig. (9) Effects of adding banana peels, corn cob and PAC on density. 
Open Access

No. 32, September 2021, pp.66-81

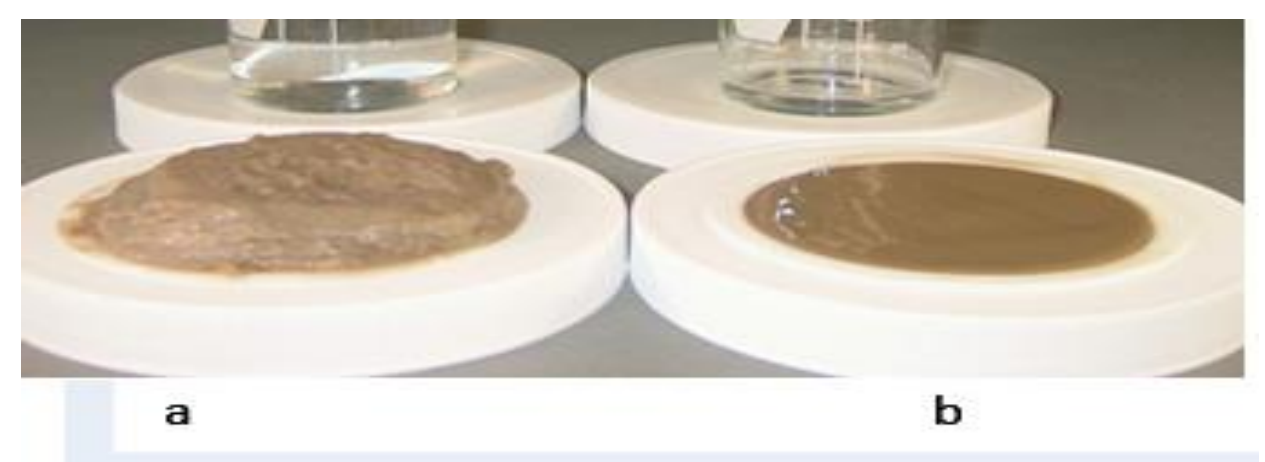

Fig. (10) A represents Iraqi bentonite mud cake without zero additives, b represents Iraqi bentonite mud cake with $6 \%$ banana peel.

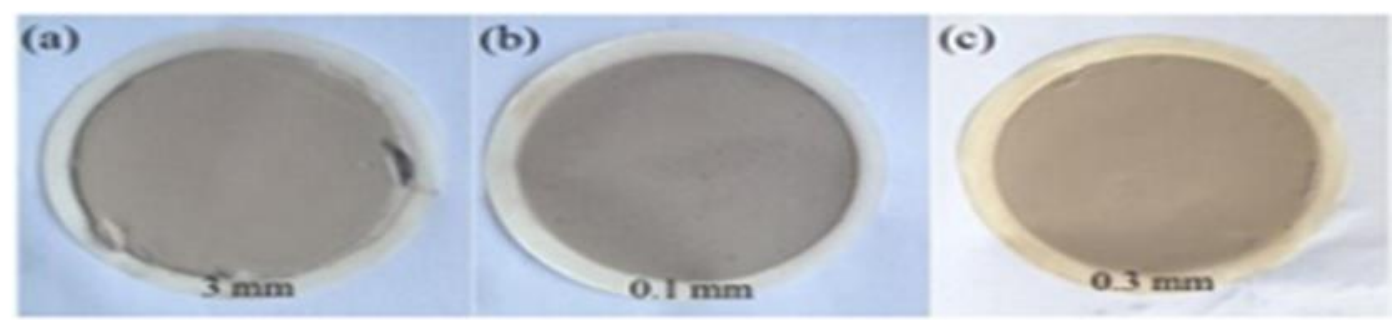

Fig. (11) (a) Mud cake with $6 \%$ corn cobs, (b) mud cake with $6 \%$ banana peel, (c) mud cake with $6 \%$ PAC

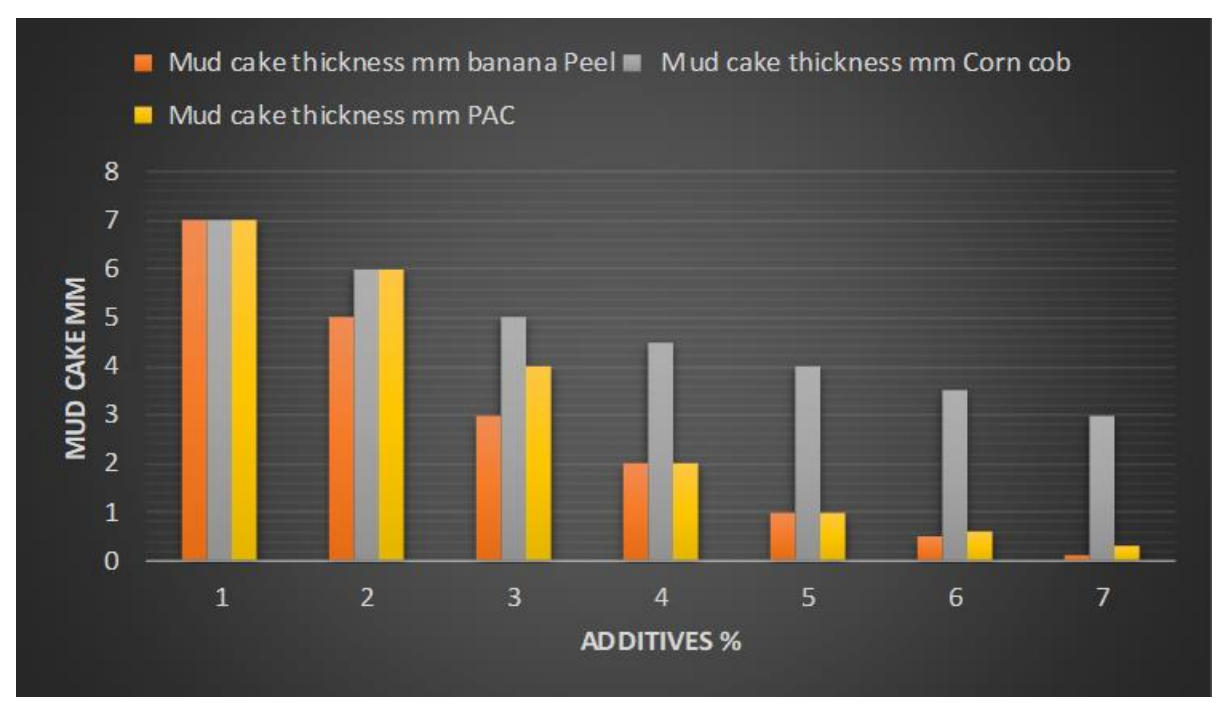

Fig. (12) Effects of adding banana peels, corn cob and PAC on mud cake thickness. 
Open Access

No. 32, September 2021, pp.66-81

P- ISSN: 2220-5381

E- ISSN: 2710-1096

Table (3) Effects of adding banana peels, corn cob and PAC on $10 \mathrm{~min}$ gel

\begin{tabular}{|c|c|c|c|c|}
\hline Additives\% & $\begin{array}{l}10 \min \text { gel } \\
\text { lb./100ft^2 }\end{array}$ & banana Peel & $\begin{array}{l}10 \text { min gel Corn cob } \\
l b . / 100 f \wedge^{\wedge} 2\end{array}$ & $\begin{array}{l}10 \text { min gel } \\
\text { lb./100ft^2 }\end{array}$ \\
\hline $\mathbf{0}$ & 1 & & 1 & 1 \\
\hline 1 & 2 & & 1.5 & 2.5 \\
\hline 2 & 3.5 & & 2.25 & 4 \\
\hline 3 & 6 & & 4.5 & 8.5 \\
\hline 4 & 9 & & 7.5 & 11 \\
\hline 5 & 13 & & 10 & 13 \\
\hline 6 & 13.5 & & 11 & 14 \\
\hline
\end{tabular}

Table (4) Effects of adding banana peels, corn cob and PAC on $10 \mathrm{~min}$ gel

\begin{tabular}{|c|c|c|c|}
\hline $\begin{array}{l}\text { Additives } \\
\%\end{array}$ & pH Banana Peel & pH Corn cob & pH PAC \\
\hline $\mathbf{0}$ & 8.6 & 8.6 & 8.6 \\
\hline 1 & 8.58 & 8.61 & 8.63 \\
\hline 2 & 8.55 & 8.62 & 8.7 \\
\hline 3 & 8.54 & 8.63 & 8.75 \\
\hline 4 & 8.53 & 8.8 & 8.8 \\
\hline 5 & 8.5 & 8.85 & 9 \\
\hline 6 & 8.48 & 9 & 9.1 \\
\hline
\end{tabular}

\section{Conclusions:}

The orientation of this research is to use environmentally- friendly and recycled materials in the oil industry in order to obtain an oil industry that is less polluting to the environment. Dried banana peels showed excellent performance as an enhancer for rheological properties and reduced filtration and have $95 \%$ similar to the performance of PAC polymer. On the other hand, the performance of corn cob is $35 \%$ lower than that of banana peels performance. The reason is due to the nature of the banana peels and because it contains a high percentage of cellulose. Although the corn cob gives performance lower than PAC and banana peels by an estimated $35 \%$, it can be used to prepare drilling fluids of low viscosity in order to 
get remarkable drilling speed and reduce the pressure loss due to friction to the minimum possible. The reason is that sometimes drilling fluids with high viscosity lead to create high pressures at the start of circulation of the drilling fluid and at download and remove the drill rod and lower the liner pipes. This causes the cracking of the layers and the loss of fluid in them. Therefore, it is evident from the above that corn cob powder can be used to prepare drilling fluids of low viscosity, and dried banana peel powder to prepare drilling fluids of high viscosity. The results prove the possibility of using dried banana peels and corn cob as good alternatives to synthetic polymers.

\section{Nomenclature}

API: American petroleum institute

$P V=$ plastic viscosity $c p$.

$P A C=$ Polynomic Cellulose Polymer

XRF: X-ray Fluorescence Analysis

$\boldsymbol{Y P}=$ yield point $\mathrm{lb} . / 100 \mathrm{ft}^{2}$. 


\section{References:}

[1] T. Al-Hameedi et al., "Laboratory Study of Environmentally Friendly Drilling Fluid Additives Banana Peel Powder for Modifying the Drilling Fluid Characteristics in Water-Based Muds", Proceedings of the International Petroleum Technology Conference (2020, Dhahran, Saudi Arabia), International Petroleum Technology Conference (IPTC), Jan 2020.

[2] Dosunmu, A., \& Joshua, O., "Development of environmentally friendly oil based mud using Palmoil and groundnut-oil", In 34th Annual SPE International Conference and Exhibition (pp. 1-9). Calabar: Society of Petroleum Engineers, (2010).

[3] Tehrani, A., Gerrard, D., Young, S., \& Fernandez, J., "Environmentally friendly water-based fluid for HPHT drilling”, In SPE International Symposium on Oilfield Chemistry (pp. 1-8). Texas: Society of Petroleum Engineers, (2009).

[4] Neff, J. M., McKelvie, S., \& Ayers, R. C. J., "Environmental impacts of synthetic based drilling fluids", U.S. Department of the interior minerals managment service. Houston, Texas, (2000).

[5] Amanullah, M., \& Yu, L., "Environment Friendly Fluid Loss Additives to Protect the Marine Environment from the Detrimental Effect of Mud Additives", Journal of Petroleum Science and Engineering, 48, 199-208, (2005).

[6] Olatunde, A. O., Usman, M. A., Olafadehan, O. A., Adeosun, T. A., \& Ufot, O. E., "Improvement of rheological properties of drilling fluid using locally based materials", Petroleum \& Coal journal, 54(1), 65-75, (2012).

[7] Kercheville, J. D., Hinds, A. A., Clements, W. R., \& Baroid, N. L., "Comparison of environmentally acceptable materials with diesel oil for drilling mud lubricity and spotting fluid formulations", IADC/SPE 14797. In IADC/SPE Drilling Conference (pp. 1-5). Dallas: IADC/SPE Drilling Conference, (1986).

[8] Adams, N. J., \& Charrier, T., "Drilling engineering: A complete well planning approach”, (T. Charrier, Ed.). Oklahoma: Penn Well Publishing Company Tulsa, Oklahoma, (1985). 
[9] Adams, N. J., \& Charrier, T., "Drilling engineering: A complete well planning approach”, (T. Charrier, Ed.), Oklahoma: Penn Well Publishing Company Tulsa, Oklahoma, (1985).

[10] I.L. Egunand Achandu M. Abah., "Comparative Performance of Cassava Starch to PAC as Fluid Loss Control Agent in Water Base Drilling Mud", Discovery 3(9), 1-4, 2013.

[11] Simpson JP, "The Drilling mud dilemma-recent examples", SPE 139278-PA Journal of petroleum technology, 1985.

[12] Moore PL, Gatlin C., "Six Variables that Effect on Penetration Rate", oil and gas journal, 1960.

[13] Akpaboi JU, "Effect of drilling fluid density on ROP", International journal of scientific innovation, 2012.

[14] Bourgoyne A.T. Jr., Millheim K.K., Chenevert M.E., and Young F.S., "Applied Drilling Engineering", Society of Petroleum Engineers Text Book Series, Vol.1, Richardson, TX, 1986.

[15] Amel H.A., "Enhancing the Lifting Capacity of Drilling Fluids in Vertical Oil Wells", Iraqi Journal of Chemical and Petroleum EngineeringVol.18 No.3 (September 2017).

[16] Matthew T. Balhoff and et. al. "Rheological and yield stress measurements of non- Newtonian fluids using a Marsh Funnel", Journal of Petroleum Science and Engineering, June, V.77, pp.393-402, 2011.

[17] Amel H.A. et al. "Studying the Effects of Different Polymers on Rheological Properties of Water Base Muds"- Journal of Engineering Number 10 Volume 23 October 2017.

[18] Assi, A. "Potato Starch for Enhancing the Properties of the Drilling Fluids. Iraqi", Journal of Chemical and Petroleum Engineering, Vol.19 No.3:33-40, 2018.

[19] Aminol M., \& Yu, L., "Environment Friendly Fluid Loss Additives to Protect the Marine Environment from the Detrimental Effect of Mud Additives”, Journal of Petroleum Science and Engineering, 48, 199-208, (2005). 